\title{
The Impact of Socio-Economic Factors on the Willingness of the Population to Maintain and Accumulate Health Capital
}

\author{
Lazat S. Spankulova ${ }^{1 *}$, Yeldar Nuruly ${ }^{1}$, Azamat R. Kerimbayev ${ }^{1}$, Aizat Sh. Aimakhanova ${ }^{2}$ \\ ${ }^{1}$ Al-Farabi Kazakh National University, 71 al-Farabi Ave., 050040, Almaty, Kazakhstan, \\ ${ }^{2}$ Asfendiyarov Kazakh National Medical University, 94 Tole bi str., 050000, Kazakhstan
}

\begin{abstract}
Purpose of the article is to identify the relationship between willingness to support, family living standards and individual's health self-assessment within the framework of the Kazakhstani population participation of in health insurance. The empirical basis of the study was the archive of sociological survey data, which is based on the population responses, taking into account the opinions in the pharmaceutical industry experts, medical workers and specialists in the insurance market. The results of the statistical analysis showed the presence of significant links between "Willingness to support" and "Self-assessment of individual health", between "Willingness to support" and "Average monthly income per capita in the family", as well as between "Willingness to support" and "Family living standards". It was also found that the willingness to support is different for different strata of the population: among the population with a high self-assessment of health, a high standard of living and a high level of per capita income in the family, it is higher. In addition, the article analyzes the current state of health insurance market in the Republic of Kazakhstan, where, as a result, it was revealed that due to quarantine measures, the number of concluded insurance contracts has almost halved. The results obtained can be used by authorized state bodies in the development of health insurance programs, as well as measures to ensure the safety of the health care system of the Republic of Kazakhstan and policies in the field of effective health care.
\end{abstract}

Keywords: willingness to pay for health care, family living standards, self-reported health, health insurance, threshold of willingness to pay for health services.

For citation: Spankulova, L.S., Nuruly, Y., Kerimbayev, A.R. \& Aimakhanova, A.Sh. (2021). The Impact of SocioEconomic Factors on the Willingness of the Population to Maintain and Accumulate Health Capital. Economics: the Strategy and Practice, 16(3), 177-191, https://doi.org/10.51176/1997-9967-2021-3-177-191

* Corresponding author: Lazat S. Spankulova - Doctor of Economics, Associate Professor, Al-Farabi Kazakh National University, 71 al-Farabi Ave., 050040, Almaty, Kazakhstan, Chief Research Fellow, +77474176754, e-mail: lyazzat.spankulova@,kaznu.kz

Conflict of interests: the authors declare that there is no conflict of interest

Financial support: The article was prepared as part of the grant funding project under the Science Committee of the Ministry of Education and Science of the Republic of Kazakhstan on the topic "Development of a quantitative methodology for identifying population groups willing to support the introduction of drug insurance and financial stability assessment of this insurance type in Kazakhstan" (IRN AP09259811).

The article received: 22.08 .2021

The article approved for publication: 31.08 .2021

Date of publication: 30.09.2021 


\title{
Әлеуметтік-экономикалық факторлардың халықтың денсаулық капиталын қолдауға және жинақтауға дайындығына әсері
}

\author{
Спанкулова Л.С. ${ }^{*}$, Нұрұлы Е. ${ }^{1}$, Керимбаев А.P. ${ }^{1}$, Аймаханова А.Ш. \\ ${ }^{1}$ әл-Фараби атындагы Қазақ ұлттық университеті, қъ., әл-Фараби д., 71, \\ 050040, Алматы, Қазақстан \\ ${ }^{2}$ С.Ж. Асфендияров атындавы Қазақ ұлттық медицина университеті, Төле би к., 94, \\ 050000, Алматы к্., Қазақсстан
}

\begin{abstract}
Түйін
Мақаланың мақсаты Қазақстан халқының медициналық сақтандыруға қатысуы шеңберінде қолдауға әзір болуы, отбасының өмір сүру деңгейі және жеке адамның денсаулығын өзін-өзі бағалауы арасындағы байланы- сты анықтау болып табылады. Зерттеудің эмпирикалық негізін фармацевтика өнеркәсібі мамандарының, медицина қызметкерлері мен сақтандыру нарығындағы мамандардың пікірлерін ескеретін, халықтың жауаптарына негізделген әлеуметтік зерттеулер деректерінің мұрағаты құрады. Статистикалық талдау нәтижелері келесі зерттелмелі факторлар «Қолдауға әзірлік» пен «Өз денсаулығын бағалау», «Қолдауға әзірлік» пен

«Отбасындағы жан басына шаққандағы орташа айлық табыс», сондай-ақ «Қолдауға әзірлік» және «Отбасының өмір сүру деңгейі» араларында маңызды байланыстардың болуын көрсетті. Сондай-ақ, халықтың әр түрлі топтары үшін қолдау көрсетуге дайындық әр түрлі екендігі анықталды: өз денсаулығын бағалауы жоғары, өмір сүру деңгейі жоғары және отбасының жан басына шаққандағы табысы жоғары тұрғындар арасында оның деңгейі де сәйкесінше жоғары. Сонымен қатар, мақалада Қазақстан Республикасындағы медициналық сақтандыру нарығының заманауи жағдайы талданған, соның нәтижесінде карантиндік шаралардың арқасында жасалған сақтандыру шарттарының саны екі есеге жуық қысқарғандығы анықталған. Алынған нәтижелерді уәкілетті мемлекеттік органдар медициналық сақтандыру бағдарламаларын, сондай-ақ Қазақстан Республикасының денсаулық сақтау жүйесінің қауіпсіздігін қамтамасыз ету шаралары мен тиімді денсаулық сақтау саласындағы саясатты әзірлеуде қолдана алады.
\end{abstract}

Түйін сөздер: денсаулықты қолдау үшін ақы төлеуге әзірлік, отбасының өмір сүру деңгейі, өз денсаулығын бағалау, медициналық сақтандыру, медициналық қызметтер үшін ақы төлеуге әзірліктің шекті шамалары.

Дәйексөз алу үшін: Спанкулова Л.С., Нұрұлы Е., Керимбаев А.Р., Аймаханова А.Ш. (2021). Әлеуметтікэкономикалық факторлардың халықтың денсаулық капиталын қолдауға және жинақтауға дайындығына әсері. Экономика: стратегия және практика, 16(3), 177-191, https://doi.org/10.51176/1997-9967-2021-3-177-191

* Хат-хабаршы авторы: Спанкулова Лазат Сейтказиевна - экономика ғылымдарының докторы, доцент, әл-Фараби атындағы Қазақ ұлттық университеті, 050040, Алматы қ., әл-Фараби даңғылы, 71, Қазақстан, бас ғылыми қызметкер, +77474176754, e-mail: lyazzat.spankulova@kaznu.kz

Мүдделер қақтығысы: авторлар мүдделер қақтығысының жоқтығын мәлімдейді.

Қаржыландыру. Мақала «Дәрілік сақтандыруды енгізуді қолдауға дайын халық топтарын анықтаудың сандық әдіснамасын әзірлеу және Қазақстанда сақтандырудың осы түрінің қаржылық тұрақтылығын бағалау» тақырыбы бойынша ҚР БҒМ Ғылым комитетінің желісі бойынша гранттық қаржыландыру жобасын іске асыру шеңберінде әзірленді (ЖТН АР09259811).

Мақала редакцияға түсті: 22.08 .2021

Жариялау туралы шешім қабылданды: 31.08 .2021

Жарияланды: 30.09 .2021 


\title{
Влияние социально-экономических факторов на готовность населения поддерживать и накапливать капитал здоровья
}

\author{
Спанкулова Л.С. ${ }^{*}$, Нурулы Е. ${ }^{1}$, Керимбаев А.Р. ${ }^{1}$, Аймаханова А.Ш.² \\ ${ }^{1}$ Казахский национальный университет имени аль-Фараби, пр. аль-Фараби, 71, \\ 50040, г. Алматы,Казахстан \\ ${ }^{2}$ Казахский национальный медицинский университет им. С.Д. Асфендиярова, ул. Толе би, 94, \\ 050000, г. Алматы, Казахстан
}

\begin{abstract}
Аннотация
Целью статьи является выявление связи между готовностью населения поддерживать и накапливать капитал здоровья, уровнем жизни семьи и самооценкой здоровья индивида в рамках участия казахстанского населения в медицинском страховании. Эмпирической основой исследования послужил архив данных социологического опроса, который опирается на ответы населения с учетом мнений экспертов фарминдустрии, медицинских работников и специалистов страхового рынка. Результаты статистического анализа показали наличие значимых связей между следующими исследуемыми факторами: «Готовностью поддержать» и «Самооценкой здоровья индивида»; «Готовностью поддержать» и «Среднемесячным доходом на душу в семье»; «Готовностью поддержать» и «Уровнем жизни семьи». Также установлено, что готовность поддержать различна у разных слоев населения: у населения с высокой самооценкой здоровья, высоким уровнем жизни и высоким уровнем дохода на душу в семье она выше. Кроме того, в статье проанализировано текушее состояние рынка медицинского страхования в Республике Казахстан, в результате которого выявлено, что из-за карантинных мер, количество заключенных договоров страхования сократилось почти в два раза. Полученные результаты могут быть использованы уполномоченными государственным органами при разработке программ медицинского страхования, а также мер по обеспечению безопасности системы здравоохранения РК и политики в области эффективного здравоохранения.
\end{abstract}

Ключевые слова: готовность платить за поддержание здоровья, уровень жизни семьи, самооценка здоровья, медицинское страхование, порог готовности платить за медицинские услуги.

Для цитирования: Спанкулова Л.С., Нурулы Е., Керимбаев А.Р., Аймаханова А.Ш. (2021). Влияние социально-экономических факторов на готовность населения поддерживать и накапливать капитал здоровья. Экономика: стратегия и практика, 16(3), 177-191, https://oi.org/10.51176/1997-9967-2021-3-177-191

* Корреспондирующий автор: Спанкулова Лазат Сейтказиевна - доктор экономических наук, доцент, Казахский национальный университет имени аль-Фараби, 050040, г. Алматы, пр. аль-Фараби, 71, Казахстан, главный научный сотрудник, +77474176754, e-mail: lyazzat.spankulova@kaznu.kz

Конфликт интересов: авторы заявляют об отсутствии конфликта интересов.

Финансирование. Статья подготовлена в рамках реализации проекта грантового финансирования по линии Комитета науки МОН РК по теме «Разработка количественной методологии выявления групп населения, готовых поддержать внедрение лекарственного страхования и оценка финансовой устойчивости этого вида страхования в Казахстане»»» (ИРН АР09259811).

Статья поступила в редакцию: 22.08 .2021

Принято решение о публикации: 31.08 .2021

Опубликовано: 30.09 .2021 


\section{Введение}

В результате распространения пандемии коронавируса в мире, казахстанская экономика столкнулась с финансовыми и экономическими проблемами. В первую очередь, Казахстан пострадал от сокращения внешнего финансирования, торговли и инвестиций. В макроэкономическом обзоре ЕАБР отмечается, что уровень ВВП Казахстана под влиянием пандемии снизился на 2,6\%1. Известно, что казахстанская экономика зависит от цены на нефть и нефтепродукты на мировом рынке энергоносителей. Доходы от реализации нефти на мировых рынках пополняют государственный бюджет. Следовательно, казахстанская экономика недополучила финансовые ресурсы. Кроме того, ужесточение ограничительных мер для населения и бизнеса со стороны государства привело к снижению предпринимательской и инвестиционной активности, росту уровня безработицы, снижению покупательской способности населения.

Нынешняя демографическая ситуация также несет в себе немало проблем. Основное из них низкая рождаемость, старение населения, большой разрыв в средней продолжительности жизни населения, высокий уровень разводов. Каждый из этих показателей ухудшают показатели здоровья населения. В настоящее время в период пандемии COVID-19 в стране неизбежно ухудшение общественного здоровья. Уровень смертности тесно связан с экономическими и социальными условиями как подъем безработицы и рост бедности среди населения. Известно, что смертность безработных и бедных значительно превышает смертность работающих и обеспеченных [1]. Информация о распространении инфекции и потерях населения, также оказывает негативное влияние на сознание людей. Последствия вынужденной гиподинамии, возможных стрессов или депрессий населения в связи c жесткой изоляцией или нежелательных поведенческих реакций также могут оказать отрицательное влияние на общественное здоровье.

В целом, казахстанская система здра-воохранения обеспечивает доступ к гарантированному объему бесплатной медицинской помощи. Однако низкий уровень здоровья граждан требует внедрения новой формы институциональной инновации медицинского страхования (лекарственного обеспечения) на условиях со-финансирования. Внедрение такого способа медицинского

\footnotetext{
1 Винокуров, Е. и др. (2021). Макроэкономический обзор ЕАБР: Сильный восстановительный рост в 2021 году. - М.: Евразийский банк развития.
}

страхования позволит обеспечить переход к новым формам государственного регулирования в сфере здравоохранения, сделать предоставление услуг по лекарственному страхованию общественно финансируемой отраслью. Стоит отметить, что здоровье не является рыночным товаром, который имеет четко определенную стоимость. Дело в том, что представление о здоровье как о бесценной категории приводит к замалчиванию темы «готовности платить».

С точки зрения перечисленных выше особенностей системы общественного здоровья в Казахстане, мы считаем актуальными направления исследований, позволяющих изучить проблемы медицинского страхования на институциональном уровне с целью выработки мер экономической политики в этой сфере. Поэтому целью настоящего исследования является выявление связи между готовностью поддержать, уровнем жизни семьи и самооценкой здоровья индивида в рамках участия казахстанского населения в медицинском страховании.

Отсюда следует гипотеза исследования: «Степень одобрения и готовности вступать в программы лекарственного страхования среди населения в Казахстане будет зависеть от уровня жизни семьи и самооценки здоровья индивида».

\section{Литературный обзор}

Современное состояние исследований по данной проблеме можно охарактеризовать как интенсивно развивающееся. Обзор предшествующих научных исследований, проведенных методом условной (субъективной) оценки в Венгрии [2], России [3-4], Китае [5], Украине [6] показывает, что готовность вступать в различные программы медицинского социального страхования зависит от демографических, социально-экономических, культурных характеристик региона или страны. Если люди готовы платить за конкретную услугу, это является явным признаком того, что она оценивается, тогда можно будет генерировать денежные средства, необходимые для поддержания аналогичных проектов [7]. В свою очередь, термин «определение порога готовности платить» означает предпочтения потребителя по отношению к изменениям в страховых услугах $[8,9]$.

Проблема оценки порога готовности платить за медицинские услуги и лекарства исследуется в разных странах на протяжении многих лет $[10,11,12]$. Позже начали осуществляться оценки предпочтительных затрат отдельных групп лиц в отношении 
товаров и услуг медицинского назначения [13, $14,15]$. Началась разработка оценок порога готовности платить, то есть оценок максимальной части дохода, которую человек готов и способен потратить на товары или услуги по лечению [16].

О.В. Зеленовой методом анкетирования случайной выборки респондентов сделана попытка определить порог готовности платить за медицинские услуги и лечение в России. В результате исследования были выделены следующие наиболее значимые факторы, влияющие на порог готовности платить в порядке убывания: статус занятости, возраст, образование респондента. В исследовании сделан вывод о том, что половой признак респондента оказывает существенно меньшее влияние на готовность платить [17].

В исследовании иранского профессора медицины Р. Мехрдад констатируется, что люди готовы платить именно за те медицинские услуги, качество которых их устраивало бы [18]. Также он называет отсутствие точных данных об удовлетворенности пациентов главным препятствием развития платных медицинских услуг в его стране. Другими словами, готовность пациентов получать платные услуги определяется уровнем удовлетворенности этими услугами.

Схожее мнение выражается в работе А. Данилова и др. [6]. Авторами был проведен эмпирический анализ возможностей осуществления официальных сборов с пациентов за медицинские услуги в Украине. Данные условной оценки, полученные от 303 респондентов, были использованы для анализа следующих вопросов: возражение против оплаты, неспособность платить и уровень готовности платить. Результаты исследования показали, что вероятность возражения против оплаты в основном определяется качественными характеристиками услуг и не связана с соответствующим поведением в реальной жизни. Вероятность неспособности платить связана с более старым возрастом, низким доходом или его отсутствием у большинства членов домохозяйства. Согласно построенной исследователями модели, уровень готовности платить за медицинские услуги у украинцев повышается на 7\% на 1000 гривен увеличения дохода.

В Казахстане работ, в которых детально анализировалась проблематика воздействия уровня жизни и дохода семьи, самооценки здоровья на готовность индивида платить за поддержание и накопление капитала здоровья, на данный момент не обнаружено.

\section{Методология}

Методология исследования строится на методах субъективной оценки нерыночных ресурсов $^{2}$ кросс-табуляционного анализа и анализа статистических связей с помощью критерия хи-квадрата Пирсона.

Для эмпирической проверки выдвинутой гипотезы мы обратились к данным социологического опроса ${ }^{3}$, проведенного в рамках проектной работы «Разработка количественной методологии выявления групп населения, готовых поддержать внедрение лекарственного страхования и оценка финансовой устойчивости этого вида страхования в Казахстане». Социологическое обследование проводилось в период с апреля по июнь 2021 года и опирается на отношение населения, экспертов, фарминдустрии и медицинских работников. На основе данных социологического опроса определяется готовность индивида платить за поддержание и накопление капитала здоровья [19]. Вопросы анкеты включают: демографическую статистику, в том числе возраст, количество детей и семейное положение; вид деятельности; уровень образования; уровень дохода семьи; использование лекарств; оценка состояния здоровья и другие. При проведении опроса авторами была налажена связь с фокус-группой среди опрашиваемых респондентов с целью дальнейшего изучения готовности поддержать населением внедрение лекарственного страхования. Данная работа проводилась с помощью инструментов онлайн-опроса «Google Forms», видеоконференций, онлайн-обсуждений посредством современных коммуникативных дистанционных технологий, таких как «Zoom», «Google Meet» и др.

Посредством кросс-табуляционного анализа были созданы таблицы сопряженности. Далее был проведен анализ статистических связей критерия хи-квадрат Пирсона в пакете SPSS Statistics.

\section{Результаты и обсуждение \\ Текущее состояние рынка медицинкого страхования в Республике Казахстан}

Анализ состояния медицинского страхования считаем необходимым начать с рассмотрения показателей рыночного управ-

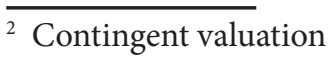

${ }^{3} \mathrm{C}$ вопросником можно ознакомится по следующей гиперссылке: https://docs.google. com/forms/d/1hOAlFvr1EbEB6CUBw__MKiGV8qb4sGOhnrWWDfXdeg/viewform? edit_ requested=true\#responses
} 
ления медицинских расходов в республике за 2008-2020 годы.

В 2020 году, в период пандемии, физические и юридические лица заключили почти 395 тысяч договоров медицинского страхова-ния на общую сумму 31,7 млрд. тенге. Значительная часть договоров страхования заключена с физическими лицами, а именно 387,7 тысяч договоров (рисунок 1). Юридические лица заключили 7310 договоров в 2020 году, при этом застрахованный персо-нал, т.е. работники компаний медицинские расходы, которых покрываются в рамках страхования составил более 300 тысяч человек ${ }^{4}$. Более того, в 2020 году, в первую очередь из-за карантинных мер, количество заключенн

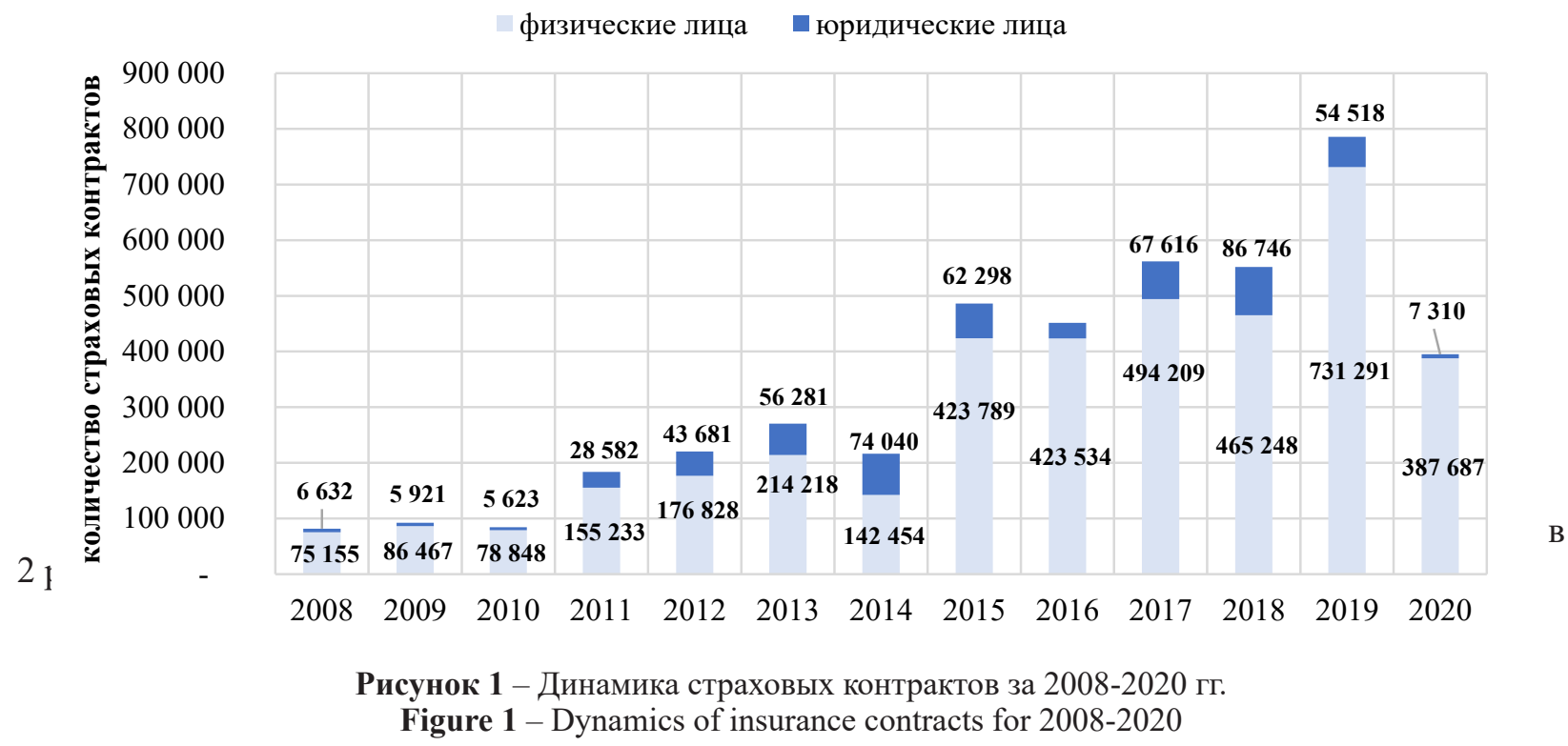

Стоит отметить, что в 2019 году, до года пандемии, добровольным медицинским страхованием было охвачено более 1,2 миллиона человек, из них около 420 тысяч

человек приобрели страховые полисы в рамках бюджета работодателей, т.е. почти 785 тысяч граждан самостоятельно купили добровольное медицинское страхование (рисунок 2).

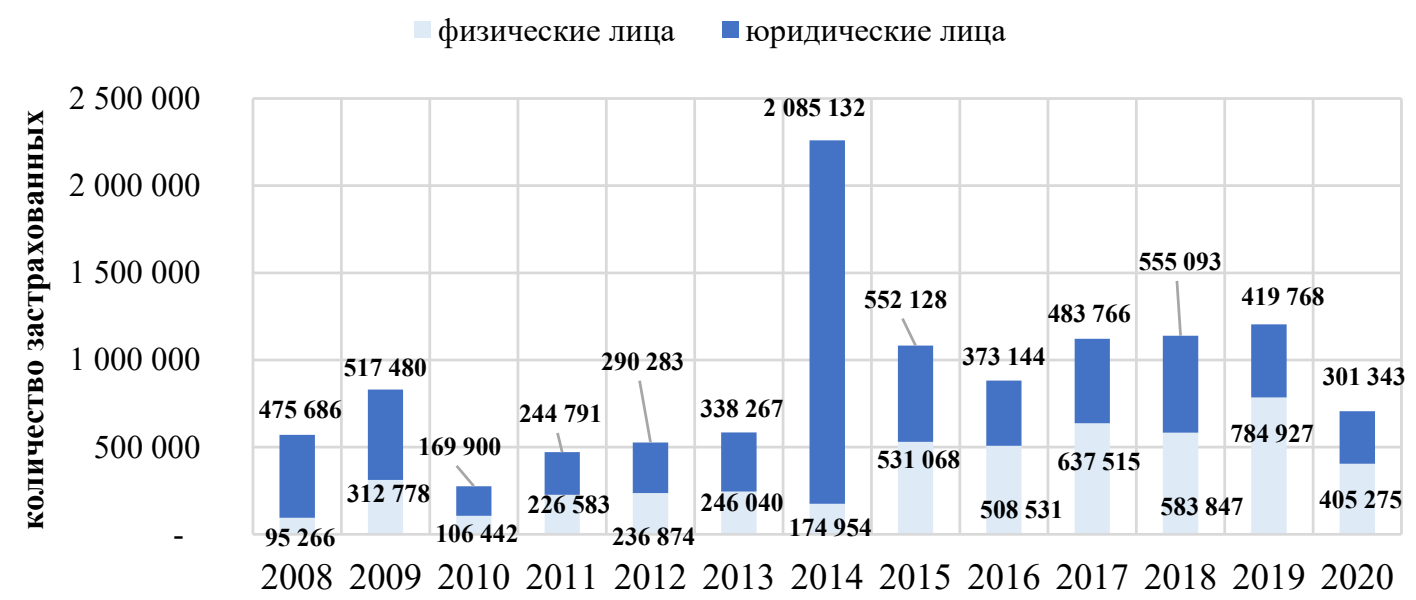

Рисунок 2 - Динамика застрахованного населения в рамках добровольного медицинского страхования

Figure 2 - Dynamics of the insured population within the framework of voluntary health insurance

\footnotetext{
${ }^{4}$ Источник: «Отраслевые данные по страховому сектору НБ РК». URL: https://nationalbank.kz
} 
На рисунке 2 представлена динамика численности застрахованного населения в рамках добровольного медицинского страхования. Начиная с 2008 года и вплоть до 2013 года, в динамике численность застрахованного населения наблюдалась стагнация. В 2014 году произошло стремительное увеличение численности застрахованных юридических лиц, а в 2015 году наоборот резкое их снижение. Далее показатель почти не менялся, лишь немного снизился в 2020 году. Отметим переломный характер показателя в 2014 году еще в одном отношении, доля застрахованных юридических лиц резко возросла. Динамика численности застрахованного населения в рамках добровольного медицинского страхования в 2017, 2018 и 2019 годы практический повторяет динамику за 2011, 2012 и 2013 годы.

Динамика численности населения за последние 5 лет, покрывающих свои медицинские расходы представлена ниже в рисунке 3. Отсюда можно заключить, что добровольное медицинское страхование, которое получило свое новое развитие в 2019 году, к сожалению, потеряло темпы роста из-за пандемии в 2020 году.

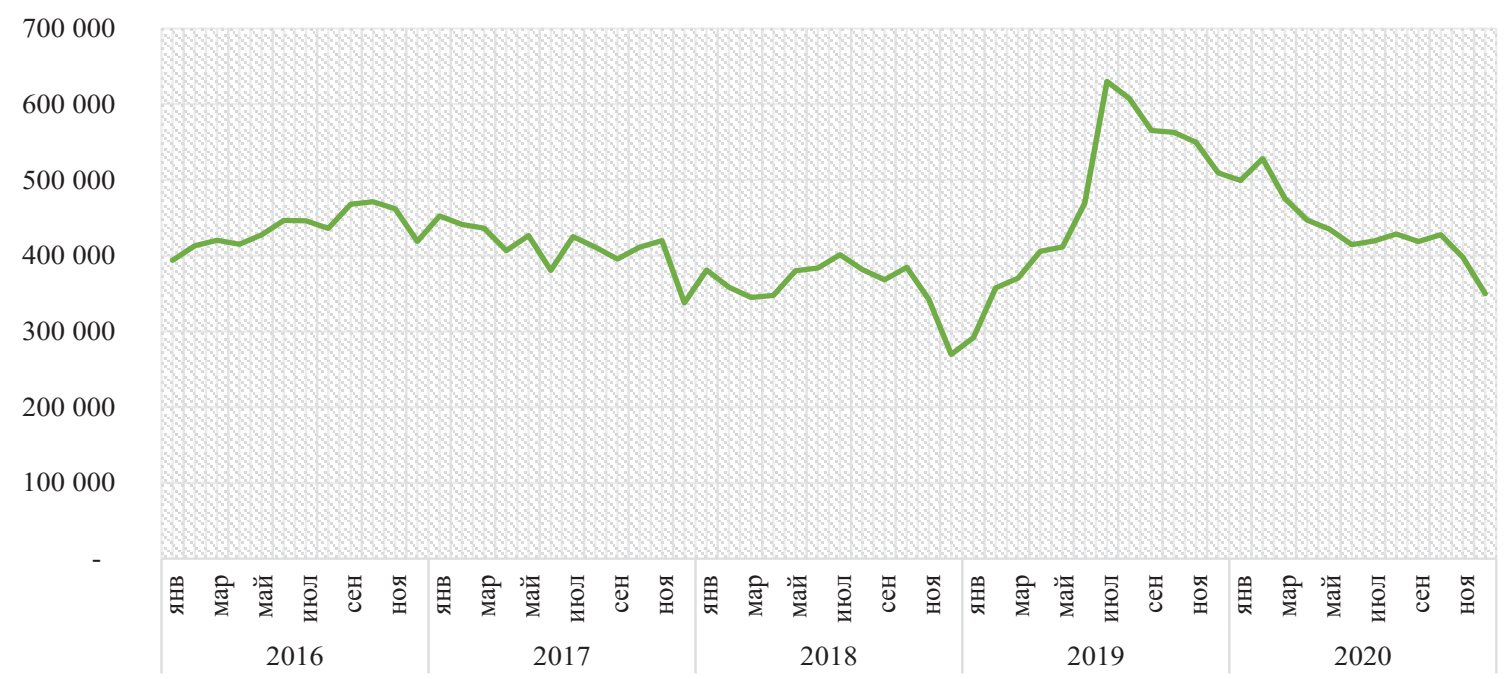

Рисунок 3 - Динамика постоянно застрахованных граждан в рамках добровольного медицинского страхования

Figure 3 - Dynamics of permanently insured citizens within the framework of voluntary health insurance

На текущий момент в Республике Казахстан зарегистрировано 27 страховых организаций. Из них 22 страховщика занимаются медицинским страхованием. Рейтинг страховых компаний по сборам страховых премий представлен ниже (таблица 1).

Как видно из таблицы 1 , ТОП-4 страховые компании в 2020 году заняли $73 \%$ всего рынка медицинского страхования. Из них 2 страховые организации занимаются исключительно медицинским страхованием: СК «ИНТЕРТИЧ» и СК «SINOASIA». Каждый страховщик, входящий в ТОП-4 рейтинга, имеет свою производственную инфраструктуру для оказания широкого спектра медицинских услуг по всей территории Республики Казахстан.
Как известно, с 1 января 2020 года в Республике Казахстан запущена система медицинского страхования (ОСМС), где государство сохраняет гарантированный объем бесплатной медицинской помощи. В связи с этим, в Казахстане на текущий момент внедряют и используют информационную систему ФСМС «Saqtandyrý», которая разработана для определения статуса пользователя медицинских услуг. От определения статуса будет зависеть как будет профинансирована помощь пациенту: за счет гарантированного бесплатного объема медицинских услуг или же расширенного страхового пакета. Однако, в данной системе численность незастрахованного населения формируется некорректно и достигает порядка 4,2 миллиона человек. 
Таблица 1 - Рейтинг страховых компаний по сборам страховых премий ${ }^{5}$

Table 1 - Rating of insurance companies by insurance premiums collection

\begin{tabular}{|c|c|c|c|c|c|c|}
\hline \multirow{2}{*}{ Страховая компания } & \multicolumn{2}{|c|}{ Сборы премий } & \multicolumn{2}{|c|}{ Доля рынка } & \multicolumn{2}{|c|}{ Изменение } \\
\hline & 2019 & 2020 & 2019 & 2020 & $\%$ & Сумма \\
\hline СК «ХАЛЫК» & 9512904 & 9169959 & $27.8 \%$ & $28.9 \%$ & $-4 \%$ & -342945 \\
\hline СК «ИНТЕРТИЧ» & 8250325 & 7250826 & $24.2 \%$ & $22.9 \%$ & $-12 \%$ & -999499 \\
\hline СК «ЕВРАЗИЯ» & 4137379 & 3527773 & $12.1 \%$ & $11.1 \%$ & $-15 \%$ & -609606 \\
\hline CK «SINOASIA» & 1876590 & 3228327 & $5.5 \%$ & $10.2 \%$ & $72 \%$ & 1351737 \\
\hline СК «ЛОНДОН» & 2911866 & 1611916 & $8.5 \%$ & $5.1 \%$ & $-45 \%$ & -1299950 \\
\hline $\mathrm{CK} « \mathrm{HCK} »$ & 1653959 & 1589282 & $4.8 \%$ & $5.0 \%$ & $-4 \%$ & -64677 \\
\hline СК «НОМАД» & 1782945 & 1035467 & $5.2 \%$ & $3.3 \%$ & $-42 \%$ & -747478 \\
\hline КСЖ «КМ» & & 1009807 & & $3.2 \%$ & & 1009807 \\
\hline СК «КОММЕСК» & 1109503 & 951033 & $3.2 \%$ & $3.0 \%$ & $-14 \%$ & -158470 \\
\hline $\mathrm{CK} \ll \mathrm{JYSAN} »$ & 926437 & 719937 & $2.7 \%$ & $2.3 \%$ & $-22 \%$ & -206500 \\
\hline CК «КАЗАХМЫС» & 945149 & 689220 & $2.8 \%$ & $2.2 \%$ & $-27 \%$ & -255929 \\
\hline CK «CEHTPAC» & 730683 & 598743 & $2.1 \%$ & $1.9 \%$ & $-18 \%$ & -131940 \\
\hline CK «AMANAT» & 233026 & 97567 & $0.7 \%$ & $0.3 \%$ & $-58 \%$ & -135459 \\
\hline $\mathrm{CK} «$ FREEDOM» & 12784 & 70854 & $0.0 \%$ & $0.2 \%$ & $454 \%$ & 58070 \\
\hline КСЖ «ЕВРОПЕЙСКАЯ» & & 45893 & & $0.1 \%$ & & 45893 \\
\hline $\mathrm{CK} « \mathrm{ACKO} »$ & 54620 & 43592 & $0.2 \%$ & $0.1 \%$ & $-20 \%$ & -11028 \\
\hline $\mathrm{CK} « \mathrm{BASEL} »$ & & 17050 & & $0.1 \%$ & & 17050 \\
\hline КСЖ «FREEDOM» & 7802 & 15936 & $0.0 \%$ & $0.1 \%$ & $104 \%$ & 8134 \\
\hline КСЖ «ХАЛЫК» & 816 & 10953 & $0.0 \%$ & $0.0 \%$ & $1242 \%$ & 10137 \\
\hline KCЖ «STANDARD» & 10697 & 9467 & $0.0 \%$ & $0.0 \%$ & $-11 \%$ & -1230 \\
\hline СК «ВИКТОРИЯ» & 4144 & 1178 & $0.0 \%$ & $0.0 \%$ & $-72 \%$ & -2966 \\
\hline КСЖ «ЕВРАЗИЯ» & & 1000 & & $0.0 \%$ & & 1000 \\
\hline Общий итог & 34161629 & 31695780 & & & $-7 \%$ & -2465849 \\
\hline
\end{tabular}

\section{Результаты социологического опроса}

В ходе исследования была сформирована эмпирическая выборка: всего в исследовании в качестве респондентов приняли участие 718 человек, где часть выборки составляла целевая аудитория телеграм-канала KERIMBAYEV ${ }^{6}$. Из них 602 человека $(83.8 \%)$ имеют высшее образование, 70 респондентов $(9.7 \%)$ неполное высшее образование (уровень бакалавра), 28 человек (3.9 \%) среднеспециальное образование, а 17 ответивших (2.4\%) имеют только среднее образование. По виду деятельности 296 человек (41.2\%) были заняты в сфере «Образование, наука, культура», 69 $(9.6 \%)$ человек были заняты в сфере «Финансы и банки», 38 (5.3\%) респондентов работают в сфере торговли и предоставления услуг, а 44 респондента (6.1\%) выбрали в качестве ответа «Другие услуги».
Из всего опрошенных 601 (83.7\%) человек проживало в городах, 53 (7.4\%) респондентов в поселках городского типа, а оставшиеся $64(8.9 \%)$ человек проживают в сельской местности.

Семейное положение следующее: 235 опрошенных (32.7\%) не состоят в зарегистрированном браке, 386 респондентов $(53.8 \%)$ состоят в зарегистрированном браке, 58 респондентов $(8.1 \%)$ разведены, а оставшиеся 22 человека $(3,1 \%)$ овдовевшие (вышеприведенные данные визуально проиллюстрированы в рисунке 4 ).

\footnotetext{
${ }^{5}$ Корпоративные отчеты страховых компаний на 1 января 2021 года.

6 Информационно-аналитический канал о страховом рынке Казахстана. Гиперссылка на канал: https://t.me/KerimbayevOnline
} 


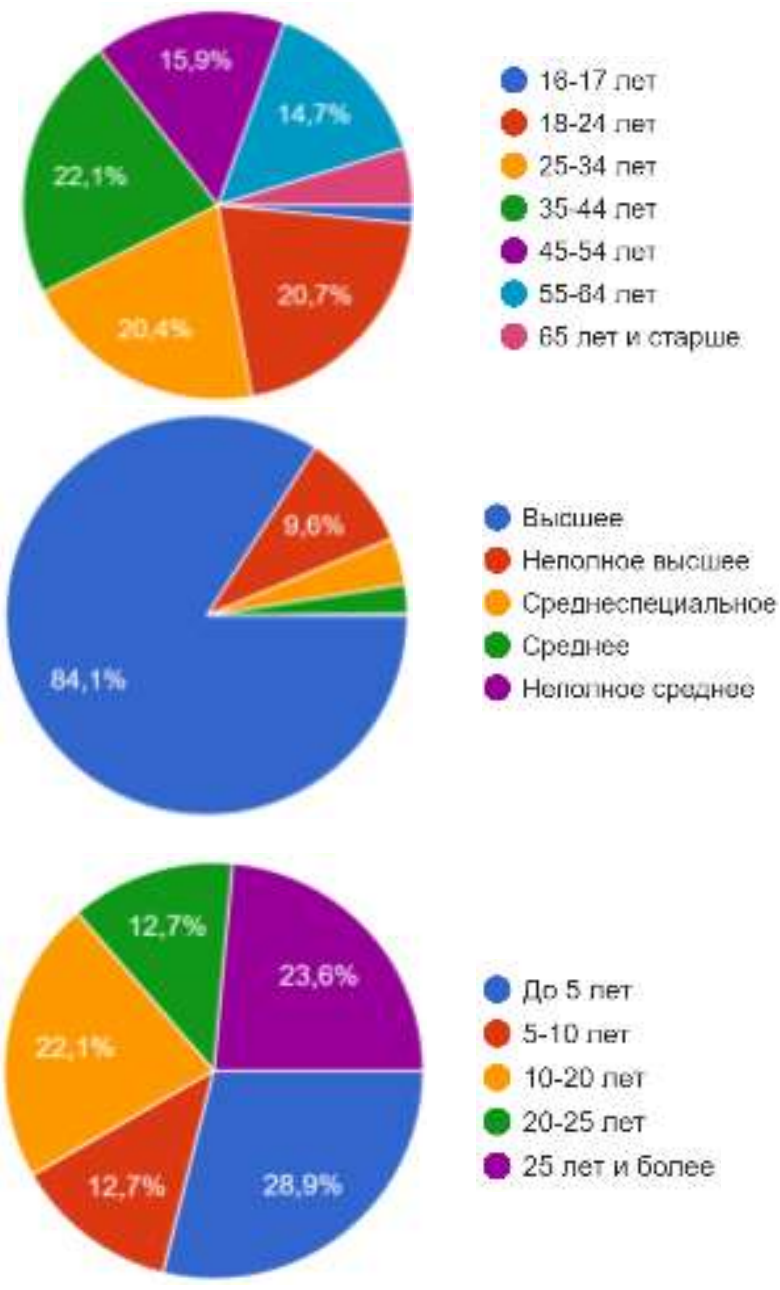

\section{Возрастной состав респондентов}

Уровень образования

\section{Стаж работы}

Рисунок 4 - Визуализированные данные эмпирической выборки

Figure 4 - Visualized empirical sample data

Сведения в разрезе регионов проживания респондентов представлены в рисунке 5 .

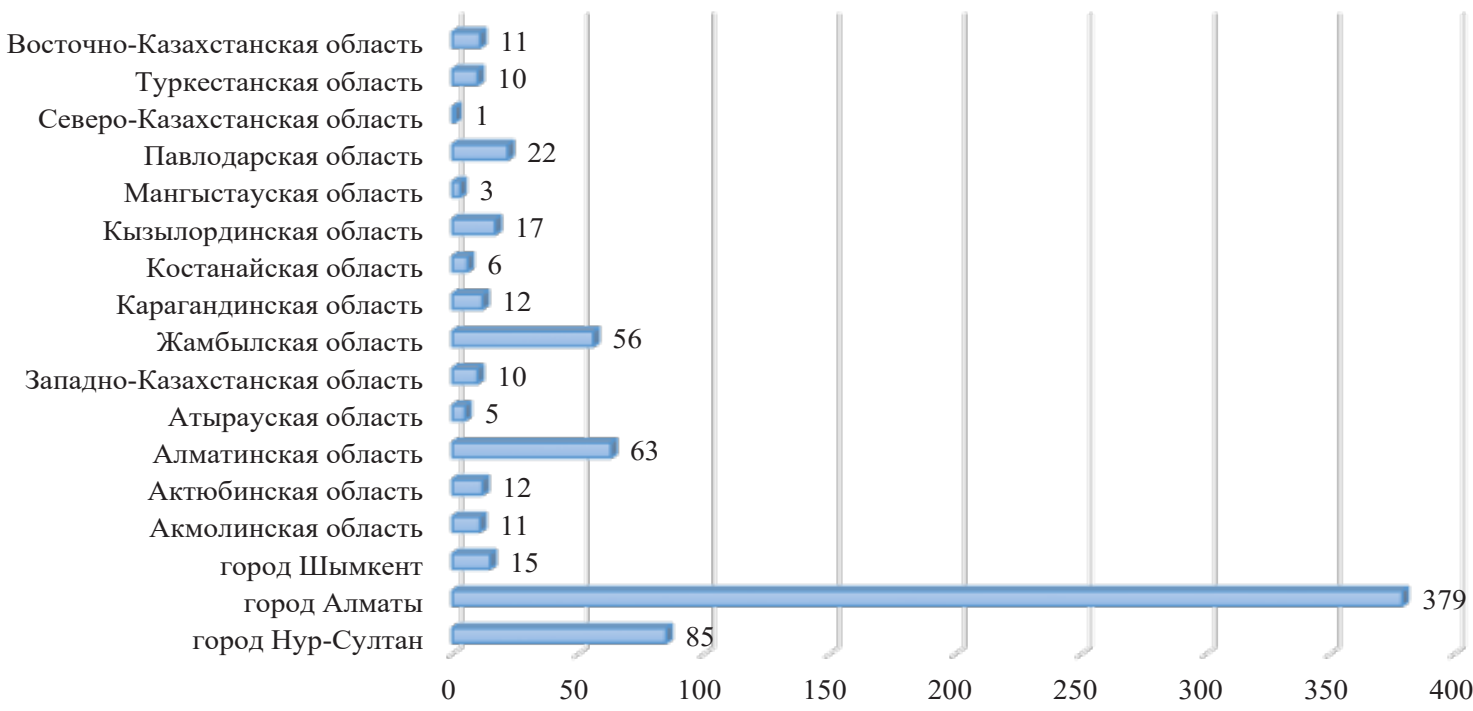

Рисунок 5 - Респонденты в разрезе регионов Казахстана

Figure 5 - Respondents by regions of Kazakhstan 
Таблица 2 - Описание данных социологического опроса

Table 2 - Description of the sociological survey data

\begin{tabular}{|l|l|}
\hline \multicolumn{1}{|c|}{ Параметры } & \multicolumn{1}{|c|}{ Описание } \\
\hline Тип выборки & $\begin{array}{l}\text { Территориальная стратифицированная случайная выборка домохозяйств. } \\
\text { Репрезентирует взрослое население страны (от 16 лет и старше) по гендеру, } \\
\text { возрастному составу, уровню образования и типу населенного пункта } \\
\text { (местожительства). }\end{array}$ \\
\hline Регионы выборки & $\begin{array}{l}\text { Опрос проводился во всех 14 областях Казахстана и в городах республиканского } \\
\text { значения Нур-Султан, Алматы и Шымкент. }\end{array}$ \\
\hline Метод исследования & $\begin{array}{l}\text { Метод случайного отбора по системе «снежный ком» (поиск через друзей и } \\
\text { знакомых, через людей, которые уже участвовали в исследовании). }\end{array}$ \\
\hline Тип доступа к данным & Открытый доступ. \\
\hline $\begin{array}{l}\text { Дополнительные } \\
\text { сведения }\end{array}$ & $\begin{array}{l}\text { Респонденту предоставляется возможность познакомиться и высказать свое } \\
\text { мнение об исследовании в целом. Для этого был указан адрес электронной } \\
\text { почты администратора опроса. }\end{array}$ \\
\hline
\end{tabular}

Для исследования и изучения статистических связей между двумя вопросами были построены комбинационные таблицы. В частности, в комбинационной таблице 3 показано совместное распределение двух переменных. Для выявления связи между переменными проведен кросс-табуляционный анализ. Проверка независимости признаков, измеренных в качественной шкале, была реализована на основе таблицы сопряженнос- ти в пакете SPSS Statistics посредством двумерного распределения. Это означает, что каждый респондент выбирает вариант по-своему в зависимости от личного опыта и личностных особенностей, то есть каждый выбирает то, что наиболее актуально для него. Для оценки сходства или различия распределений по частоте встречаемости тех или иных качественных признаков применены непараметрические критерии.

Таблица 3 - Результаты распределения ответов на вопросы анкеты под № 1 и № 4

Table 3 - Results of answers distribution to the questionnaire questions under No. 1 and No. 4

\begin{tabular}{|c|c|c|c|c|c|c|c|}
\hline & \multicolumn{5}{|c|}{$\begin{array}{l}\text { 1. Готовы ли Вы приобрести полис лекарственного } \\
\text { страхования? }\end{array}$} & \multirow[b]{2}{*}{ Всего } \\
\hline & & да & $\begin{array}{l}\text { затрудняюсь } \\
\text { ответить }\end{array}$ & $\begin{array}{c}\text { не } \\
\text { знаю }\end{array}$ & нет & $\begin{array}{c}\text { отказ } \\
\text { от } \\
\text { ответа }\end{array}$ & \\
\hline \multirow{5}{*}{$\begin{array}{l}\text { 4. Самооценка } \\
\text { здоровья? }\end{array}$} & Отличное & 76 & 6 & 12 & 21 & 2 & 117 \\
\hline & Очень плохое & 1 & 0 & 0 & 0 & 0 & 1 \\
\hline & Плохое & 3 & 9 & 1 & 3 & 0 & 16 \\
\hline & Удовлетворительное & 116 & 22 & 45 & 37 & 2 & 222 \\
\hline & Хорошее & 198 & 33 & 54 & 77 & 0 & 362 \\
\hline \multicolumn{2}{|r|}{ Всего } & 394 & 70 & 112 & 138 & 4 & 718 \\
\hline
\end{tabular}

Как можно заметить из таблицы 4 критерии и V Крамера, Пирсона, Пирсона с поправкой на правдоподобие, коэффициента неопределенности и критерии -Гудмана и Краскала показывают связь между «Готовностью поддержать» и «Самооценкой здоровья индивида».

На основе полученных результатов расчета (см. таблицу 4) сделан вывод, что респонденты действительно готовы участво*вать и поддерживать внедрение лекарственн- ого страхования, если в своем стремлении поддерживается самосохранительное поведение. Все остальное имеет меньшую значимость.

В таблице 6 представлены статистические характеристики критериев Тау-b и Тау-c Кендалла, а также $\gamma$ Гудмена-Краскела, доказывающих наличие значимых статистических связей между «Готовностью поддержать» и «Среднемесячным доходом на душу в семье». 
Таблица 4 - Результаты анализа категориальных данных с помощью статистических критериев на основе таблиц сопряженности (вопросы № 1 и № 4)

Table 4 - Results of categorical data analysis using statistical criteria based on the conjugacy tables (questions No. 1 and No. 4)

\begin{tabular}{|l|l|}
\hline Критерий Пирсона & $=58,541 ; \mathrm{df}=16 ; \mathrm{p}=0,000$ \\
\hline Критерий Пирсона с поправкой на правдоподобие & $=43,174 ; \mathrm{df}=16 ; \mathrm{p}=0,000$ \\
\hline Критерий Крамера &, $286 ; \mathrm{P}=0,000$ \\
\hline Критерий V Крамера & $\mathrm{V}=0,143 ; \mathrm{P}=0,000$ \\
\hline Критерий Коэффициент сопряженности Пирсона & $\mathrm{C}=0,275 ; \mathrm{P}=0,000$ \\
\hline Критерий коэффициент неопределенности & $\mathrm{U}=0,025 ; \mathrm{P}=0,000^{\mathrm{d}}$ \\
\hline Критерий -Гудмана и Краскала &, $012 ;, 012$ \\
\hline
\end{tabular}

Примечание - df (degress of freedom) - число степеней свободы, Р - доступный уровень статистической значимости.

Таблица 5 - Результаты распределения ответов на вопросы анкеты под № 1 и № 15

Table 5 - Results of answers distribution to the questionnaire questions under No. 1 and No. 15

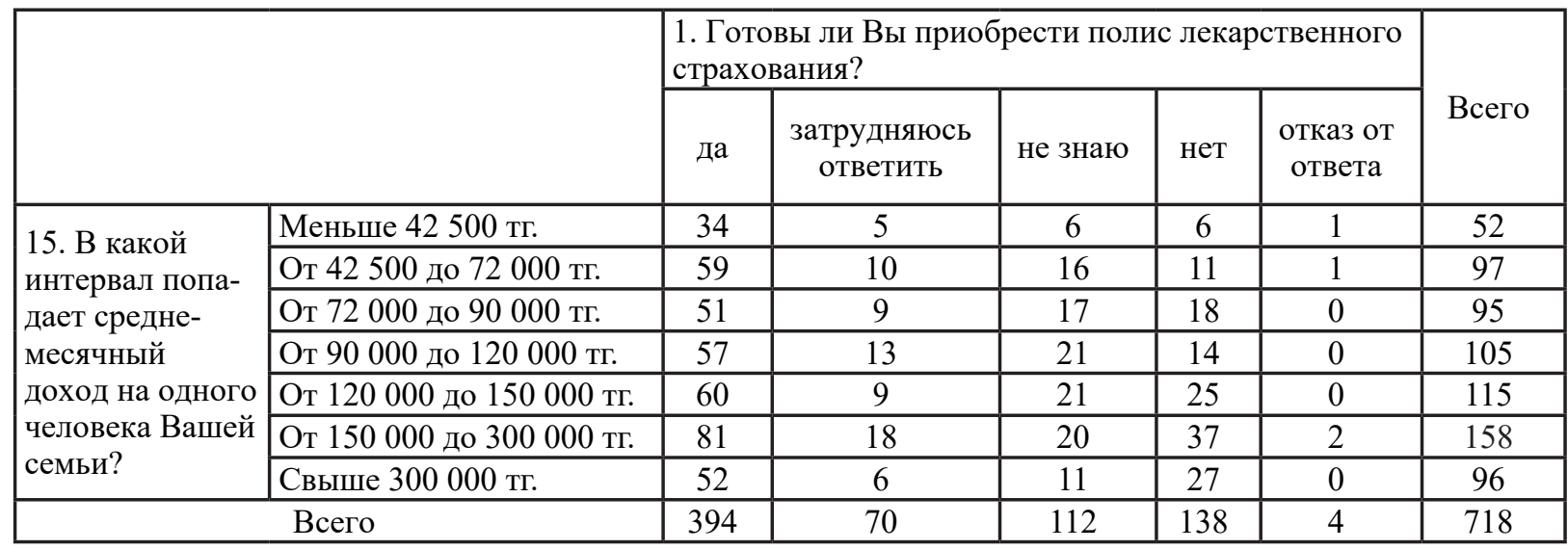

Таблица 6 - Результаты анализа категориальных данных с помощью статистических критериев на основе таблиц сопряженности (вопросы № 1 и № 15)

Table 6 - Results of categorical data analysis using statistical criteria based on the conjugacy tables (questions No. 1 and No. 15)

\begin{tabular}{|l|l|}
\hline Критерий Тау-b Кендалла & $=0,068 ; \mathrm{P}=0,026$ \\
\hline Критерий Тау-с Кендалла & $=0,062 ; \mathrm{P}=0,026$ \\
\hline Критерий Гудмена-Краскела & $=0,093 ; \mathrm{P}=0,026$ \\
\hline
\end{tabular}

В комбинационной таблице 7 представлен кросс-табуляционный анализ между «Готовностью поддержать» и «Уровнем жизни семьи» с пятью вариантами ответов.
Как видно из таблицы 8 критерии Пирсона, Пирсона с поправкой на правдоподобие, Макнемара-Баукера, и V Крамера и критерий коэффициента сопряженности Пирсона демонстрируют связь на среднем уровне между «Готовностью поддержать» и «Уровнем жизни семьи» (таблица 8).

Как можно заметить из таблицы 8, в определенной степени объяснительную силу имеет фактор материальной обеспеченности [20], так как имеется возможность предположить, что ее могут поддерживать, прежде всего, наиболее обеспеченные респонденты. С помощью медицинского страхования у респондентов открывается доступ к жизненно необходимым и ранее недосягаемым лекарствам [20]. 
Таблица 7 - Результаты распределения ответов на вопросы анкеты под № 1 и № 11

Table 7 - Results of answers distribution to the questionnaire questions under No. 1 and No. 11

\begin{tabular}{|c|c|c|c|c|c|c|c|}
\hline & \multicolumn{5}{|c|}{$\begin{array}{l}\text { 1. Готовы ли Вы приобрести полис } \\
\text { лекарственного страхования? }\end{array}$} & \multirow{2}{*}{ Всего } \\
\hline & & да & $\begin{array}{c}\text { затрудняюсь } \\
\text { ответить }\end{array}$ & $\begin{array}{c}\text { не } \\
\text { знаю }\end{array}$ & нет & $\begin{array}{c}\text { отказ от } \\
\text { ответа }\end{array}$ & \\
\hline \multirow{5}{*}{$\begin{array}{l}\text { 11. Как бы } \\
\text { Вы могли } \\
\text { охарактеризовать } \\
\text { уровень жизни } \\
\text { своей семьи? } \\
\text { Выберите } \\
\text { наиболее } \\
\text { подходящее } \\
\text { высказывание }\end{array}$} & $\begin{array}{l}\text { Финансовых средств сейчас } \\
\text { не хватает даже на покупку } \\
\text { продуктов питания }\end{array}$ & 18 & 4 & 7 & 4 & 1 & 34 \\
\hline & $\begin{array}{l}\text { Финансовых средств сейчас } \\
\text { хватает только на покупку } \\
\text { продуктов питания }\end{array}$ & 49 & 8 & 13 & 15 & 1 & 86 \\
\hline & $\begin{array}{l}\text { Финансовых средств хвата- } \\
\text { ет для приобретения необхо- } \\
\text { димых продуктов питания } \\
\text { и одежды, более крупные } \\
\text { покупки приходится откла- } \\
\text { дывать на потом }\end{array}$ & 204 & 37 & 61 & 58 & 0 & 360 \\
\hline & Затрудняюсь ответить & 25 & 7 & 11 & 22 & 2 & 67 \\
\hline & $\begin{array}{l}\text { Приобретение товаров дли- } \\
\text { тельного пользования у нас } \\
\text { не вызывает трудностей, } \\
\text { но приобретение автотран- } \\
\text { спорта, дачного участка и } \\
\text { др. нам сейчас недоступна }\end{array}$ & 98 & 14 & 20 & 39 & 0 & 171 \\
\hline & Всего & 394 & 70 & 112 & 138 & 4 & 718 \\
\hline
\end{tabular}

Таблица 8 - Результаты анализа категориальных данных с помощью статистических критериев на основе таблиц сопряженности (вопросы № 1 и № 11)

Table 8 - Results of categorical data analysis using statistical criteria based on the conjugacy tables (questions No. 1 and No. 11)

\begin{tabular}{|l|l|}
\hline Критерий Пирсона & $=32,275 ; \mathrm{df}=16 ; \mathrm{p}=0,009$ \\
\hline $\begin{array}{l}\text { Критерий Пирсона с поправкой } \\
\text { на правдоподобие }\end{array}$ & $=29,356 ; \mathrm{df}=16 ; \mathrm{p}=0,022$ \\
\hline Критерий Макнемара-Баукера & $; \mathrm{df}=10 ; \mathrm{P}=0,000$ \\
\hline Критерий & $\mathrm{V}=0,212 ; \mathrm{P}=0,009$ \\
\hline Критерий V Крамера & $\mathrm{V}=0,106 ; \mathrm{P}=0,009$ \\
\hline $\begin{array}{l}\text { Критерий Коэффициент } \\
\text { сопряженности Пирсона }\end{array}$ & $\mathrm{C}=0,207 ; \mathrm{P}=0,009$ \\
\hline
\end{tabular}

Таким образом, проведенный кросстабуляционный анализ и анализ статистических связей критерий хи-квадрат Пирсона подтвердили гипотезу настоящего исследования. Можно сделать вывод о том, что программа, должна быть направлена на помощь больным. Очевидно, что интерес в присоединении к программе лекарственного обеспечения должны проявлять группы населения, испытывающие нужды при покупке жизненно необходимых лекарств.

\section{Заключение}

В результате изучения взаимосвязи между социально-экономическими характеристиками и готовностью населения платить за поддержание и накопление капитала здоровья удалось выявить значимые факторы, достоверно связанные с готовностью поддержать.

Во-первых, самым значимым фактором оказалась самооценка здоровья. Это статистически достоверно по критерию хи-квадрат Пирсона. Готовность поддержать зависит от уровня самооценки здоровья: чем выше самоцценка, тем выше готовность поддержать. Если лица с удовлетворительной самооценкой здоровья готовы поддержать в 
29 \% случаев, то лица с хорошей самооценкой здоровья готовы поддержать в 50 \% случаев.

Во-вторых, значимым фактором оказался «среднемесячный доход на душу в семье». Готовность поддержать зависит от уровня доходов на душу в семье: чем выше доход, тем выше готовность поддержать. Если лица с среднемесячным доходом на душу в семье от 72000 до 90000 тенге готовы поддержать в $12 \%$ случаев, то среди лиц с доходом на душу в семье более 150000 тенге в месяц «готовы поддержать» в $21 \%$ случаев.

В-третьих, значимым фактором оказался уровень жизни семьи. Готовность поддержать зависит от уровня жизни семьи: чем выше уровень жизни семьи, тем выше готовность поддержать. Если лица с высоким уровнем жизни готовы поддержать в 52 \% случаев, то среди лиц с низким уровнем жизни готовы поддержать в 4 \% случаев.

Таким образом, готовность поддержать различна у разных слоев населения: у населения с высокой самооценкой здоровья, высоким уровнем жизни и высоким уровнем дохода на душу в семье она выше. Полученный результат может указывать на один из факторов, определяющих сложившееся в нашей стране неравенство в здоровье, связанное с доходом.

\section{Список использованных источников}

1 Currie, J., \& Schwandt, H. (2016). Mortality inequality: The good news from a county-level approach. The Journal of Economic Perspectives, 30(2), 29-52. https://doi.org/10.1257/jep.30.2.29

2 Baji, P., et al. (2014). The link between past informal payments and willingness of Hungarian population to pay formal fees for health care services: results from a contingent valuation study. European Journal of Health Economics, 15(8), 853-867. https:// doi.org/10.1007/s10198-013-0531-y

3 Канева М.А., Авксентьев Н.А., \& Байдин В. М. (2015). Готовность платить за добровольное медицинское страхование на условиях софинансирования: регрессионный анализ. Финансовый журнал, 5(27), 80-90.

4 Gerry, C.J., Kaneva, M., \& Zasimova, L. (2017). Reforming voluntary drug insurance in Russian healthcare: does social solidarity matter? Health policy, 121(11), 1177-1185. https://doi.org/10.1016/j. healthpol.2017.09.001

5 Zhang, L., et al. (2006). Social capital and farmer's willingness-to-join a newly established community-based health insurance in rural China. Health policy, 76(2), 233-242. https://doi.org/10.1016/j. healthpol.2005.06.001

6 Danyliv, A., et al. (2013). Willingness to pay for physician services at a primary contact in Ukraine: results of a contingent valuation study.
BMC Health Services Research, 13, 208. https://doi. org/10.1186/1472-6963-13-208

7 Yasunaga, H. (2008). Willingness to pay for mass screening for prostate cancer: A contingent valuation survey. International Journal of Urology, 15(1), 102-105.

8 Ягудина Р.И. и др. (2015). Определение порога «готовности платить» при одобрении медицинских технологий в условиях российского здравоохранения, рассчитанного на основе паритета покупательной способности. Фармакоэкономика: теория и практика, 3(3), 5-9.

9 Кацнельсон Б.А. и др. (2007). Концепция «приемлемого» риска - ключевой дискуссионный вопрос оценки и управления рисками для здоровья населения. Гигиена и санитария, 3, 76-80.

10 Gyrd-Hansen, D. (2003). Willingness to pay for a QALY. Health Economics, 12, 1049-1060.

11 Laupacis, A., et al. (1992). How attractive does a new technology have to be to warrant adoption and utilization? Tentative guidelines for using clinical and economic evaluations. Canadian Medical Association Journal, 146, 473-481.

12 Kaplan, R. M. \& Bush, J. W. (1982). Healthrelated quality of life measurement for evaluation research and policy analysis. Health Psychology, 1, 61-80.

13 Ubel, P.A., et al. (2003). What is the price of life and why doesn't it increase at the rate of inflation? Archives of Internal Medicine, 163, 1637-1664.

14 Hirth, R.A., et al. (2000). Willingness to pay for a quality-adjusted life year: in search of a standard. Medical Decision Making, 20, 32-34.

15 Тепцова Т.С. и др. (2018). Возможные методики определения порога готовности платить для принятия решений о финансировании технологий здравоохранения за счет бюджетных средств. Фармакоэкономика. Современная фармакоэкономика и фармакоэпидемиология, 11(3), 13-22. https://doi.org/10.17749/2070-4909.2018.11.3-013-022

16 Tambor, M., et al. (2014). Willingness to pay for publicly financed health care services in Central and Eastern Europe: Evidence from six countries based on a contingent valuation method. Social Science \& Medicine, 116, 193-201.

17 Зеленова О.В. (2011). Исследование определения порога готовности платить методом условной оценки за услуги медицинского назначения и лечение. Социальные аспекты здоровья населения, 21 (5), 7-17.

18 Mehrdad, R. (2009). Health System in Iran. JMAJ, 52(1), 69-73.

19 Спанкулова Л.С. (2016). Удовлетворенность качеством жизни, связанного со здоровьем в зависимости от уровня доходов населения, проживающих в областях с высоким экологическим риском. Психологическое здоровье личности: теория и практика: сборник научных трудов по материалам III Всероссийской научно-практической конференции, 128-130.

20 Новицкая К. Е. (2009). Индивидуальные стратегии участников госпрограммы дополнительного лекарственного обеспечения. Социологические исследования, 5(301), 59-69. 


\section{References}

1 Currie, J., \& Schwandt, H. (2016). Mortality inequality: The good news from a county-level approach. The Journal of Economic Perspectives, 30(2), 29-52. https://doi.org/10.1257/jep.30.2.29

2 Baji, P., et al. (2014). The link between past informal payments and willingness of Hungarian population to pay formal fees for health care services: results from a contingent valuation study. European Journal of Health Economics, 15(8), 853-867. https:// doi.org/10.1007/s10198-013-0531-y

3 Kaneva, M.A., Avksent'ev, N.A., \& Bajdin, V.M. (2015). Gotovnost' platit' za dobrovol'noe medicinskoe strahovanie na uslovijah sofinansirovanija: regressionnyj analiz. Finansovyj zhurnal, 5(27), 80-90.

4 Gerry, C.J., Kaneva, M., \& Zasimova, L. (2017). Reforming voluntary drug insurance in Russian healthcare: does social solidarity matter? Health policy, 121(11), 1177-1185. https://doi.org/10.1016/j. healthpol.2017.09.001

5 Zhang, L., et al. (2006). Social capital and farmer's willingness-to-join a newly established community-based health insurance in rural China. Health policy, 76(2), 233-242. https://doi.org/10.1016/j. healthpol.2005.06.001

6 Danyliv, A., et al. (2013). Willingness to pay for physician services at a primary contact in Ukraine: results of a contingent valuation study. BMC Health Services Research, 13, 208. https://doi. org/10.1186/1472-6963-13-208

7 Yasunaga, H. (2008). Willingness to pay for mass screening for prostate cancer: A contingent valuation survey. International Journal of Urology, 15(1), 102-105.

8 Jagudina, R.I. i dr. (2015). Opredelenie poroga «gotovnosti platit'» pri odobrenii medicinskih tehnologij $\mathrm{v}$ uslovijah rossijskogo zdravoohranenija, rasschitannogo na osnove pariteta pokupatel'noj sposobnosti. Farmakojekonomika: teorija i praktika, 3(3), 5-9.

9 Kacnel'son, B.A. i dr. (2007). Koncepcija «priemlemogo» riska - kljuchevoj diskussionnyj vopros ocenki i upravlenija riskami dlja zdorovıja naselenija. Gigiena i sanitarija, 3, 76-80.

10 Gyrd-Hansen, D. (2003). Willingness to pay for a QALY. Health Economics, 12, 1049-1060.
11 Laupacis, A., et al. (1992). How attractive does a new technology have to be to warrant adoption and utilization? Tentative guidelines for using clinical and economic evaluations. Canadian Medical Association Journal, 146, 473-481.

12 Kaplan, R.M. \& Bush, J.W. (1982). Healthrelated quality of life measurement for evaluation research and policy analysis. Health Psychology, 1, 61-80.

13 Ubel, P.A., et al. (2003). What is the price of life and why doesn't it increase at the rate of inflation? Archives of Internal Medicine, 163, 1637-1664.

14 Hirth, R.A., et al. (2000). Willingness to pay for a quality-adjusted life year: in search of a standard. Medical Decision Making, 20, 32-34.

15 Tepcova, T.S. i dr. (2018). Vozmozhnye metodiki opredelenija poroga gotovnosti platit' dlja prinjatija reshenij o finansirovanii tehnologij zdravoohranenija za schet bjudzhetnyh sredstv. Farmakojekonomika. Sovremennaja farmakojekonomika i farmakojepidemiologija, 11(3), 13-22. https://doi.org/10.17749/2070-4909.2018.11.3013-022

16 Tambor, M., et al. (2014). Willingness to pay for publicly financed health care services in Central and Eastern Europe: Evidence from six countries based on a contingent valuation method. Social Science \& Medicine, 116, 193-201.

17 Zelenova, O.V. (2011). Issledovanie opredelenija poroga gotovnosti platit' metodom uslovnoj ocenki za uslugi medicinskogo naznachenija $\mathrm{i}$ lechenie. Social'nye aspekty zdorov'ja naselenija, 21 (5), 7-17.

18 Mehrdad, R. (2009). Health System in Iran. JMAJ, 52(1), 69-73.

19 Spankulova, L.S. (2016). Udovletvorennost' kachestvom zhizni, svjazannogo so zdorov'em $\mathrm{v}$ zavisimosti ot urovnja dohodov naselenija, prozhivajushhih v oblastjah s vysokim jekologicheskim riskom. Psihologicheskoe zdorov'e lichnosti: teorija $i$ praktika: sbornik nauchnyh trudov po materialam III Vserossijskoj nauchno-prakticheskoj konferencii, 128130.

20 Novickaja, K E. (2009). Individual'nye strategii uchastnikov gosprogrammy dopolnitel'nogo lekarstvennogo obespechenija. Sociologicheskie issledovanija, 5(301), 59-69.

\section{Information about the authors}

*Lazat S. Spankulova - Doctor of Economics, Associate Professor, Al-Farabi Kazakh National University, Chief Research Fellow, Kazakhstan, e-mail: 1yazzat.spankulova@kaznu.kz, ORCID ID: https://orcid.org/0000-0002$\underline{1865-4681}$

Yeldar Nuruly - PhD student, Al-Farabi Kazakh National University, , Research Fellow Lecturer, Kazakhstan, e-mail: yeldar.nuruly@,kaznu.kz. ORCID ID: https://orcid.org/0000-0002-9321-2285

Azamat R. Kerimbayev - PhD, Al-Farabi Kazakh National University, Senior Research Fellow, Kazakhstan, e-mail: azamat@kerimbayev.com. ORCID ID: https://orcid.org/0000-0001-6125-2728 
Aizat Sh. Aimakhanova - Candidate of Physical and Mathematical Sciences, Associate Professor of Mathematics, Asfendiyarov Kazakh National Medical University, Kazakhstan, e-mail:aizat.68@mail.ru. ORCID ID: https://orcid. org/0000-0001-9724-8720

\section{Авторлар туралы мәліметтер}

* Спанкулова Лазат Сейтказиевна - экономика ғылымдарының докторы, доцент, әл-Фараби атындағы Қазақ ұлттық университеті, бас ғылыми қызметкер, Қазақстан, e-mail: lyazzat.spankulova@kaznu.kz, ORCID ID: https://orcid.org/0000-0002-1865-4681

Нұрұлы Елдар - PhD-докторант, әл-Фараби атындағы Қазақ ұлттық университеті, ғылыми қызметкер, оқытушы, Қазақстан, e-mail: yeldar.nuruly@kaznu.kz. ORCID ID: https://orcid.org/0000-0002-9321-2285

Керимбаев Азамат Рашидович - PhD, әл-Фараби атындағы Қазақ ұлттық университеті, аға ғылыми қызметкер, Қазақстан, e-mail: azamat@,kerimbayev.com. ORCID ID: https://orcid.org/0000-0001-6125-2728

Аймаханова Айзат Шалхаровна - физика-математика ғылымдарының кандидаты, математика доценті, C.Ж. Асфендияров атындағы Қазақ ұлттық медицина университеті, Қазақстан, e-mail:_aizat.68@mail.ru. ORCID ID: https://orcid.org/0000-0001-9724-8720

\section{Сведения об авторах}

* Спанкулова Лазат Сейтказиевна - доктор экономических наук, доцент, Казахский национальный университет имени аль-Фараби, главный научный сотрудник, Казахстан, e-mail: lyazzat.spankulova@kaznu. kz, ORCID ID: https://orcid.org/0000-0002-1865-4681

Нурулы Елдар - PhD-докторант, Казахский национальный университет имени аль-Фараби, научный сотрудник, преподаватель, Казахстан, e-mail: yeldar.nuruly@kaznu.kz. ORCID ID: https://orcid.org/0000-0002$\underline{9321-2285}$

Керимбаев Азамат Рашидович - PhD, Казахский национальный университет имени аль-Фараби, старший научный сотрудник, Казахстан, e-mail: azamat@kerimbayev.com. ORCID ID: https://orcid.org/0000-0001-6125$\underline{2728}$

Аймаханова Айзат Шалхаровна - кандидат физико-математических наук, доцент математики, Казахский национальный медицинский университет им. С.Д. Асфендиярова, Казахстан, e-mail:aizat.68@,mail.ru. ORCID ID: https://orcid.org/0000-0001-9724-8720 